\title{
Free Amino Acids in the Caput and the Cauda Epididymis of Adult Rats
}

\author{
JUn SHIMAZAKI*, Hidetoshi YAMANAKA, \\ IoE TAGUCHI AND KeIzo SHIDA \\ Department of Urology, School of Medicine, \\ Gunma University, Maebashi-shi, Gunma-ken 371
}

\begin{abstract}
Synopsis
To examine the content and the composition of free amino acids in the intraluminal fluid of rat epididymis, the fluids were obtained by light pressure on the dissected tissues. The amount of the total free amino acids in the pressed fluid from the caput epididymis was significantly higher than those of the cauda epididymis and the testis. Glu and Gln were predominant amino acids in the caput, and their amounts occupied more than half of the total ninhydrin reactive compounds. Such a high concentration of Glu and Gln was not observed either in the cauda or in the testis. Castration decreased Glu and increased Gln in amount. Testosterone treatment to castrated animals did not restore Glu and Gln contents in the pressed fluid from the caput epididymis to the level observed in intact rats completely. Therefore, it was assumed that a large amount of Glu in the caput was due to many factors; secretion and metabolism of epithelial cells of the gland which might be regulated by androgen, inflow of rete testis fluid, and sperm metabolism of amino acids in the epididymis. The results obtained from the caput epididymis to which the efferent duct of the testis was ligated also supported this interpretation.
\end{abstract}

The mammalian spermatozoa acquire ability of fertilization and motility during passage through the epididymis (OrgebinCrist, 1969). Migration of cytoplasmic droplet, morphological alteration of acrosome and changes in -S-S- linked structure of sperm tail were observed along with sperm maturation in the epididymis (Hamilton, 1972; Bedford and Calvin, 1974). Factors affecting the sperm maturation have been extensively discussed, and it has been recognized that the environment of the epididymal canal might influence the maturation steps (Dyson and Orgebin-Crist, 1973; Burgos and Tovar, 1974).

Received for publication December 28, 1975.

* Present address, Department of Urology, School of Medicine, Chiba University, Chiba-shi, Chibaken 280 .
Fluids from two sources seem to contribute to the epididymal canal; rete testis fluid and secretory product of the epididymis (Setchell, 1974). Testosterone and dihydrotestosterone, and androgen-binding protein have been detected in the epididymis (Hansson et al., 1973a,b; Ganjam and Amann, 1973; Ritzen et al., 1973; French and Ritzen, 1973; Weddington et al., 1974; Danzo et al., 1974; Cooper and Waites, 1974; Back, 1975; Tindall et al., 1975). These were derived from the testis as the component of the rete testis fluid. It was also reported that androgen promotes the sperm maturation (Orgebin-Crist, 1973).

The growth and the secretory state of the epididymis are dependent on androgens (Hamilton, 1972; Rajalakshmi and Prasad, 1971; Riar et al., 1973). Glycerylphosphoryl- 
choline, carnitine and sialic acid were secreted from the epididymis, and the secretion of these substances was regulated by androgens, however, the role of these substances in sperm maturation is still unknown. The biochemical environment of the epididymis has not fully been understood, therefore, the analysis of free amino acids in the rat epididymis has been performed to throw a further insight into the characteristics of this organ.

\section{Materials and Methods}

\section{Animals}

Male Wistar rats weighing $350-600 \mathrm{~g}$ were used throughout the experiments. Animals were maintained with water and standard laboratory chow (CE-2, Clea Co., Japan) in a room of constant temperature $\left(24^{\circ} \mathrm{C}\right)$. Castration was performed via scrotal route under ether anesthesia. Testosterone enanthate dissolved in sesame oil was subcutaneously injected by $5 \mathrm{mg}$ per head on the day of castration and 10 days after the operation, respectively.

\section{Tissue preparation}

Animals were sacrificed by cervical dislocation and the epididymis and the testis were removed. Caput and cauda of the epididymis, which were separated according to the description of Reid and Cleland (1957), were pooled separately on ice. Tissues were cut into small pieces and were pressed with a metal plate manually. A small amount of fluid was oozed from a cut surface, then a small volume of distilled water was added to the pressed tissues. The tissues were mixed with distilled water, spun at $700 \times g$ for two min and the supernatant was saved. Tissues were rinsed again with a small amount of distilled water, and after centrifugation the supernatant was combined and used for amino acid analysis. All procedures were performed under the cold condition. The tissue architecture was histologically well preserved after such manipulation, therefore, it was assumed that most of the amino acids in the supernatant obtained in this way were derived from fluid in the epididymal canal, and probably to a less extent, if any, from fluid in the other space of the organ. A term "pressed fluid" was used hereafter for this material. In some experiments the epididymis and the testis were homogenized in a glass homogenizer with 5 -fold volume of distilled water, and free amino acids in the homogenate were determined.
Measurement of free amino acids

Samples to be analysed were mixed with the same amount of $2 \%$ picric acid (w/v) and spun at $1200 \times g$ for $10 \mathrm{~min}$. The resultant supernatant was applied to a Dowex 2-X8 column and free amino acids were eluted according to the method of Stein and Moore (1954). To oxidize cystein to cystine alkalization of samples was carried out for $6 \mathrm{hrs}$. An aliquot of the samples was analysed for individual amino acids with a Liquid Chromatograph (Hitachi Model 034, Japan) by the method of Spackman et al. (1958). Total amount of free amino acids was calculated as the sum of each amount of individual amino acids.

\section{Results}

Free amino acids in pressed fluids of the caput and the cauda epididymis, and the testis from adult rats

Samples of pressed fluids were prepared from the caput and the cauda epididymis and the testis from adult rats and were served for amino acid determination (Table 1). Weight of the bilateral tissues per $100 \mathrm{~g}$ body weight were as follows; $107.2 \pm 2.8 \mathrm{mg}$ to the caput, $115.7 \pm 6.1$ to the cauda and $625.0 \pm 10.0$ to the testis. The pressed fluid from the caput contained a significantly larger amount of the total amino acids than that either from the cauda or from the testis, due mainly to the high content of Glu which was about ten times as much as those found in other two organs. Moreover, in the pressed fluid from the caput, the contents of Pro, Phe, Asp, Ala, P-ser and Tau differed from significantly those in the cauda, and the contents of Pro, Cys/2, Tyr, Phe and His significantly differed from those in the testis. These results indicated that the pressed fluid from the caput showed a characteristic pattern in the constituent of free amino acids.

Comparison of free amino acids in the pressed fluid and the homogenate of the caput and the cauda epididymis, and the testis from adult rats

The homogenates of two regions of the epididymis and the testis were analysed for free amino acid contents. The total amount 
of free amino acids in the homogenates was higher than that in the pressed fluids of corresponding tissues, therefore, mol \% of individual amino acid was used for comparison (Table 2). The pattern of free amino acids in the homogenate of the testis was almost sirislar to that in the pressed fluid of the same organ. The homogenate of the caput contained a larger amount of Gln than the pressed fluid of the same organ. Glu was the second predominant amino acid in the homogenate of the caput. The homogenate of the cauda contained Gln more dominantly than the pressed fluid, though the ratio of Gln in the homogenate to that in the pressed fluid was lower than that observed in the caput.

Table 1. Free amino acids in the pressed fluids of the epididymis and the testis from adult rats.

\begin{tabular}{|c|c|c|c|c|c|c|}
\hline & \multirow{2}{*}{$\begin{array}{l}\text { Caput } \\
\text { epididymis }(4)^{\text {a) }}\end{array}$} & \multirow{2}{*}{$\begin{array}{l}\text { Cauda } \\
\text { epididymis (4) }\end{array}$} & \multirow[b]{2}{*}{ Testis (4) } & \multicolumn{3}{|c|}{ Statistics ${ }^{b)}$} \\
\hline & & & & $\begin{array}{l}\text { Caput } \\
\text { to } \\
\text { Cauda }\end{array}$ & $\begin{array}{l}\text { Caput } \\
\text { to } \\
\text { Testis }\end{array}$ & $\begin{array}{l}\text { Cauda } \\
\text { to } \\
\text { Testis } \\
\end{array}$ \\
\hline $\begin{array}{l}\text { Total } \\
\text { amount }\end{array}$ & $19.3 \pm 1.6$ & $9.6 \pm 1.1$ & $12.6 \pm 1.4$ & 0.005 & 0.025 & \\
\hline Asp & $0.34 \pm 0.05$ & $0.142 \pm 0.000$ & $0.23 \pm 0.01$ & 0.005 & & 0.005 \\
\hline Asn & $0.04 \pm 0.02$ & $0.02 \pm 0.01$ & $0.03 \pm 0.02$ & & & \\
\hline Thr & $0.35 \pm 0.09$ & $0.19 \pm 0.01$ & $0.15 \pm 0.02$ & & & \\
\hline Ser & $0.33 \pm 0.09$ & $0.227 \pm 0.000$ & $0.17 \pm 0.03$ & & & \\
\hline Glu & $10.5 \pm 0.4$ & $0.92 \pm 0.06$ & $1.3 \pm 0.1$ & 0.005 & 0.005 & 0.025 \\
\hline $\mathrm{Gln}$ & $1.6 \pm 0.6$ & $1.3 \pm 0.3$ & $1.6 \pm 0.4$ & & & \\
\hline Pro & $0.17 \pm 0.03$ & $0.08 \pm 0.01$ & $0.43 \pm 0.07$ & 0.05 & 0.01 & 0.005 \\
\hline Gly & $1.1 \pm 0.3$ & $1.06 \pm 0.05$ & $1.1 \pm 0.1$ & & & \\
\hline Ala & $0.93 \pm 0.10$ & $0.33 \pm 0.03$ & $0.63 \pm 0.08$ & 0.005 & & 0.025 \\
\hline Cys/2 & $0.39 \pm 0.05$ & $0.28 \pm 0.01$ & $0.096 \pm 0.000$ & & 0.005 & 0.005 \\
\hline Val & $0.15 \pm 0.07$ & $0.078 \pm 0.000$ & $0.11 \pm 0.05$ & & & \\
\hline Met & $0.06 \pm 0.04$ & $0.017 \pm 0.003$ & $0.025 \pm 0.000$ & & & \\
\hline Ile & $0.09 \pm 0.03$ & $0.046 \pm 0.001$ & $0.04 \pm 0.01$ & & & \\
\hline Leu & $0.14 \pm 0.03$ & $0.092 \pm 0.000$ & $0.09 \pm 0.02$ & & & \\
\hline Tyr & $0.08 \pm 0.01$ & $0.053 \pm 0.000$ & $0.04 \pm 0.01$ & & 0.05 & \\
\hline Phe & $0.08 \pm 0.01$ & $0.049 \pm 0.000$ & $0.04 \pm 0.01$ & 0.025 & 0.01 & \\
\hline Lys & $0.29 \pm 0.13$ & $0.16 \pm 0.01$ & $0.20 \pm 0.03$ & & & \\
\hline $\mathrm{His}$ & $0.10 \pm 0.02$ & $0.041 \pm 0.000$ & $0.029 \pm 0.002$ & & 0.05 & \\
\hline Arg & $0.06 \pm 0.01$ & $0.033 \pm 0.000$ & $0.10 \pm 0.02$ & & & 0.025 \\
\hline $\mathrm{P}$-ser & $0.11 \pm 0.03$ & $0.05 \pm 0.01$ & $0.10 \pm 0.03$ & 0.05 & & \\
\hline PEA & $1.7 \pm 0.8$ & $3.5 \pm 0.6$ & $1.12 \pm 0.13$ & & & 0.025 \\
\hline Tau & $0.64 \pm 0.08$ & $0.91 \pm 0.06$ & $2.4 \pm 1.3$ & 0.05 & & \\
\hline Sar & 0.000 & trace & $2.3 \pm 0.1$ & & & \\
\hline Cit & $0.004 \pm 0.000$ & trace & $0.11 \pm 0.05$ & & & \\
\hline$\beta$-Ala & $0.02 \pm 0.01$ & $0.027 \pm 0.000$ & 0.000 & & & \\
\hline
\end{tabular}

Data are shown as $\mathrm{M} \pm \mathrm{S}$.E. of $\mu$ moles in the pressed fluid obtained from one gram of tissue.

a) Numbers in parentheses are the number of experiments performed independently. In each experiment, 10 rats were used.

b) Statistical differences by student $t$ test among three organs were calculated. Values shown in the Table are significantly different ( $\mathrm{p}$ is less than the value). The method for the preparation of the pressed fluids from the organs was described in the text. 
Free amino acids in the pressed fluids of the caput and the cauda epididymis from castrated and castrated testosterone-treated rats

Adult rats were castrated and sacrificed 3 weeks after the operation (castrated rats). Some of the castrated animals each received $5 \mathrm{mg}$ of testosterone enanthate on the day of castration and ten days after the operation, and were sacrificed on the 21st day of post-operation (castrated testosterone-treated rats). The weights $(\mathrm{mg} / 100 \mathrm{~g}$ body weight) of the caput and the cauda of castrated rats were $22.2 \pm 1.9$ and $34.2 \pm 1.6$, respectively, and those of castrated testosterone-treated rats were $81.4 \pm 7.2$ and $88.9 \pm 9.3$, respectively. The contents of free amino acids in the respective pressed fluids of these tissues were shown in Table 3.

Between intact and castrated animals, there was no significant difference in the total amount of free amino acids in the pressed fluids of the caput, however, significant differences in the free amino acid composition were observed in these two groups. The most remarkable change after castration was the decrease in Glu and the in-

Table 2. Amount of free amino acids in the pressed fluids and the homogenates expressed on the basis of Mol. percent.

\begin{tabular}{|c|c|c|c|c|c|c|}
\hline \multirow[b]{3}{*}{ Asp } & \multicolumn{2}{|c|}{ Caput epididymis } & \multicolumn{2}{|c|}{ Cauda epididymis } & \multicolumn{2}{|c|}{ Testis } \\
\hline & P.F. ${ }^{a)}$ & Homog. & P.F. & Homog. & P.F. & Homog. \\
\hline & 1.77 & 1.26 & 1.48 & 1.52 & 1.86 & 2.33 \\
\hline Asn & 0.19 & 0.00 & 0.25 & 0.32 & 0.22 & 0.36 \\
\hline Thr & 1.80 & 1.51 & 2.01 & 1.32 & 1.26 & 0.84 \\
\hline Ser & 1.69 & 1.62 & 2.37 & 1.90 & 1.38 & 0.87 \\
\hline Glu & 54.45 & 36.07 & 9.63 & 9.83 & 10.70 & 11.12 \\
\hline Gln & 8.47 & 27.26 & 13.41 & 19.75 & 13.00 & 16.40 \\
\hline Pro & 0.90 & 0.63 & 0.83 & 0.50 & 3.39 & 3.82 \\
\hline Gly & 5.51 & 6.58 & 11.09 & 9.64 & 9.00 & 8.12 \\
\hline Ala & 4.80 & 4.02 & 3.43 & 2.63 & 4.97 & 5.47 \\
\hline Cys $/ 2$ & 2.01 & 2.10 & 2.89 & 2.77 & 0.76 & 0.84 \\
\hline Val & 0.79 & 0.45 & 0.82 & 0.46 & 0.89 & 0.30 \\
\hline Met & 0.30 & 0.11 & 0.18 & 0.13 & 0.20 & 0.16 \\
\hline Ile & 0.45 & 1.44 & 0.48 & 0.30 & 0.33 & 0.18 \\
\hline Leu & 0.72 & 0.49 & 0.96 & 0.51 & 0.75 & 0.64 \\
\hline Tyr & 0.42 & 0.30 & 0.55 & 0.29 & 0.34 & 0.17 \\
\hline Phe & 0.43 & 0.31 & 0.51 & 0.43 & 0.32 & 0.26 \\
\hline Lys & 1.50 & 0.57 & 1.63 & 1.19 & 1.57 & 0.99 \\
\hline His & 0.49 & 0.24 & 0.43 & 0.35 & 0.23 & 0.22 \\
\hline Arg & 0.33 & 0.12 & 0.35 & 0.24 & 0.78 & 0.53 \\
\hline P-ser & 0.59 & 0.35 & 0.51 & 0.44 & 0.79 & 0.34 \\
\hline PEA & 8.93 & 10.40 & 36.40 & 33.56 & 8.86 & 7.04 \\
\hline $\mathrm{Tau}$ & 3.32 & 3.85 & 9.53 & 11.89 & 19.12 & 11.67 \\
\hline Sar & 0.00 & 0.00 & 0.00 & 0.00 & 18.53 & 27.27 \\
\hline Cit & 0.02 & 0.12 & 0.00 & 0.00 & 0.89 & 0.00 \\
\hline$\beta$-Ala & 0.12 & 0.17 & 0.28 & 0.00 & 0.00 & 0.00 \\
\hline
\end{tabular}

a) P.F.; pressed fluids, Homog.; homogenate.

Mol. percent was calculated from moles of each amino acid divided by moles of the total amino acids. Mol. percent in P.F. was calculated from data in the Table 1.

Values in the homogenate were the average from three independent determinations. In each determination, 8 rats were used. The total amount of free amino acids in the homogenates were $38.9 \pm 1.3,12.4 \pm 1.4$ and $24.0 \pm 3.9 \mu$ moles/g wet weight of tissues for the caput, the cauda and the testis, respectively. 
crease in Gln content. The sum of Glu and Gln after castration was also reduced in comparison with intact animals. Testosterone treatment to castrated rats increased the amounts of Glu and Gln in the caput, however the Glu content still remained in lower level than the intact ones.

In the pressed fluids from the cauda, the total amount of free amino acids was significantly increased after castration. In this case, most of the amino acids was evenly increased. When the content of amino acids was computed into mol \%, no significant changes were observed after castration. Free amino acids in the pressed fluid from castrated testosterone-treated rats showed

Table 3. Effect of castration and testosterone treatment on free amino acids in the pressed fluids of the epididymis.

\begin{tabular}{|c|c|c|c|c|}
\hline & \multicolumn{2}{|c|}{ Caput epididymis } & \multicolumn{2}{|c|}{ Cauda epididymis } \\
\hline & Castration (3) ${ }^{\text {a) }}$ & $\begin{array}{l}\text { Castration- } \\
\text { testosterone } \\
\text { treated }(2) \\
\end{array}$ & Castration (3) & $\begin{array}{l}\text { Castration- } \\
\text { testosterone } \\
\text { treated }(2) \\
\end{array}$ \\
\hline $\begin{array}{l}\text { Total } \\
\text { amount }\end{array}$ & $20.5 \pm 1.4$ & 15.5 & $14.7 \pm 0.5^{* *}$ & 10.7 \\
\hline Asp & $0.45 \pm 0.05$ & 0.196 & $0.31 \pm 0.03_{* *}^{* *}$ & 0.169 \\
\hline Asn & $0.23 \pm 0.04^{* *}$ & 0.097 & $0.12 \pm 0.06$ & 0.124 \\
\hline Thr & $0.51 \pm 0.03$ & 0.252 & $0.41 \pm 0.09^{*}$ & 0.266 \\
\hline Ser & $0.57 \pm 0.06$ & 0.292 & $0.36 \pm 0.04 * *$ & 0.305 \\
\hline Glu & $2.07 \pm 0.37_{* *}^{* *}$ & 5.547 & $1.66 \pm 0.37$ & 1.080 \\
\hline Gln & $5.75 \pm 1.11^{* *}$ & 2.414 & $2.48 \pm 0.63$ & 1.608 \\
\hline Pro & $0.25 \pm 0.01^{*}$ & 0.098 & $0.16 \pm 0.02^{*}$ & 0.123 \\
\hline Gly & $2.45 \pm 0.16^{* *}$ & 1.303 & $1.72 \pm 0.16^{* * *}$ & 1.230 \\
\hline Ala & $1.19 \pm 0.13$ & 0.905 & $0.63 \pm 0.03^{* * *}$ & 0.440 \\
\hline Cys $/ 2$ & $0.67 \pm 0.03^{* *}$ & 0.267 & $0.49 \pm 0.07^{* *}$ & 0.353 \\
\hline Val & $0.25 \pm 0.03$ & 0.106 & $0.20 \pm 0.01_{* *}^{* *}$ & 0.104 \\
\hline Met & $0.16 \pm 0.06$ & 0.019 & $0.10 \pm 0.03 *$ & 0.021 \\
\hline Ile & $0.185 \pm 0.000 * *$ & 0.060 & $0.13 \pm 0.01_{* *}^{* *}$ & 0.065 \\
\hline Leu & $0.34 \pm 0.02^{* *}$ & 0.112 & $0.25 \pm 0.02_{* *}^{* *}$ & 0.125 \\
\hline Tyr & $0.14 \pm 0.02^{*}$ & 0.059 & $0.11 \pm 0.01{ }_{* *}^{* *}$ & 0.068 \\
\hline Phe & $0.17 \pm 0.01^{* *}$ & 0.064 & $0.125 \pm 0.000_{* *}^{* *}$ & 0.071 \\
\hline Luys & $0.44 \pm 0.06$ & 0.222 & $0.42 \pm 0.08 * *$ & 0.197 \\
\hline His & $0.10 \pm 0.02$ & 0.058 & $0.09 \pm 0.01 * *$ & 0.061 \\
\hline Arg & $0.13 \pm 0.02^{* *}$ & 0.046 & $0.09 \pm 0.02 * *$ & 0.051 \\
\hline $\mathrm{P}$-ser & $0.08 \pm 0.02$ & 0.125 & $0.039 \pm 0.000$ & 0.045 \\
\hline PEA & $3.90 \pm 0.35$ & 2.511 & $3.87 \pm 0.24$ & 3.015 \\
\hline $\mathrm{Tau}$ & $0.48 \pm 0.12$ & 0.744 & $0.96 \pm 0.18$ & 1.202 \\
\hline Sar & 0.000 & 0.000 & 0.000 & 0.000 \\
\hline Cit & trace & 0.011 & $0.02 \pm 0.01$ & 0.009 \\
\hline$\beta$-Ala & 0.000 & trace & 0.000 & 0.000 \\
\hline
\end{tabular}

Data are shown as $\mathrm{M} \pm$ S.E. or mean of two expriments of $\mu$ moles in the pressed fluid obtained from one gram of tissue.

a) Numbers in parentheses are the number of experiments performed indendepently. In each experiment 10 animals were used.

b) Statistically different from intact rats $\left.{ }^{*} ; \mathrm{p}<0.05, * * ; \mathrm{p}<0.02, * * * ; \mathrm{p}<0.01, * * * \mathrm{p}<0.005\right)$

Animals were sacrificed on the 21 st day after castration. When testosterone treatment was carried out, testosterone enanthate was injected by $5 \mathrm{mg}$ per head on the day of castration and 10 days after the operation, respectively. 
only a slight change in the amount of individual amino acids from intact animals. Therefore, free amino acids in the pressed fluids of the cauda seem to be independent of the hormonal status of animals.

Effect of ligation of the efferent duct of testis on free amino acids of the caput epididymis

As shown in the former section, the caput contained a large amount of Glu in the pressed fluid. To eliminate the inflow of rete testis fluid and spermatozoa, the efferent duct was unilaterally ligated and the epididymis of the intact side was served for the control. Three weeks after the operation animals were sacrificed and amino acid contents in the pressed fluids of the caput were determined. The weights of the caput were $42.5 \pm 6.5 \mathrm{mg} / 100 \mathrm{~g}$ body weight in the duct ligated side and $51.9 \pm 3.5$ in the non-operative side. No statistical difference was found between them.

The amount of the total amino acids in the caput was reduced by ligation, mainly due to the decrease in the amount of Glu (Table 4). The result suggested that a large amount of Glu in the pressed fluid of the caput was attributable to the presence of spermatozoa in the caput, and that Glu might be accumulated in the consequence of metabolism in spermatozoa in the canal of the caput.

\section{Discussion}

Sexton et al. (1971) reported that the fluid derived from the vas deferens of a bull contained the higher concentration of free amino acids than that from the rete testis and accessory sex gland, and that the predominant amino acid in such fluid was glutamate. However, the total amount of glutamate in the rete testis fluid per $24 \mathrm{hrs}$ was larger than that in the vas deferens fluid. This indicates that the inflow of glutamate to the epididymis from testis and the reten- tion of this amino acid in the epididymis seem to influence the amount of glutamate in the tissue. Mushahwar and Koeppe (1973) reported a free amino acid composition of the rat testis in which the amount of Glu and Gln was approximately one fourth of the total amino acids. The relatively high content of these amino acids among free amino acids in the testis was also observed

Table 4. Effect of ligation of the efferent duct on free amino acids in the caput epididymis.

\begin{tabular}{lcc}
\hline \hline Total & Ligation & Control $^{\text {a) }}$ \\
amount & 15.2 & 21.4 \\
Asp & 0.419 & 0.309 \\
Asn & 0.134 & trace \\
Thr & 0.410 & 0.135 \\
Ser & 0.343 & 0.127 \\
Glu & 3.704 & 11.773 \\
Gln & 1.413 & 1.864 \\
Pro & 0.129 & 0.095 \\
Gly & 1.912 & 1.222 \\
Ala & 0.789 & 0.801 \\
Cys $/ 2$ & 0.415 & 0.413 \\
Val & 0.116 & 0.047 \\
Met & 0.040 & 0.008 \\
Ile & 0.085 & 0.040 \\
Leu & 0.165 & 0.087 \\
Tyr & 0.067 & 0.063 \\
Phe & 0.085 & 0.079 \\
Lys & 0.209 & 0.149 \\
His & 0.067 & 0.081 \\
Arg & 0.022 & 0.056 \\
P-ser & 0.031 & 0.127 \\
PEA & 3.530 & 3.046 \\
Tau & 1.154 & 0.865 \\
Sar & 0.000 & 0.000 \\
Cit & trace & 0.000 \\
$\beta-A l a$ & 0.000 & 0.000 \\
\hline
\end{tabular}

Data are shown as $\mu$ moles in the pressed fluid obtained from one gram of tissue.

a) Right efferent duct was ligated and cut off, and left side was left intact to serve a control. In an experiment, 15 rats were used and sacrificed on 21 st day after operation.

Values obtained from the operative side and the non-operative side were compared. Two series of experiments were performed and a typical result is shown in the Table. 
in the present study. Tuck et al. (1970) reported the low concentration of Glu in the rete testis fluid from rats. Therefore, a large amount of Glu in the pressed fluid of the caput epididymis observed in the present experiments does not seem to be only due to the inflow of glutamate from the testis. It is assumed that Glu accumulation in the caput was due to many factors; inflow of the rete testis fluid, metabolic sequence of amino acids by spermatozoa during maturation, and secretion and metabolism of epithelial cells of the caput canal.

Spermatozoa contain glutamic oxaloacetic transaminase (Pace and Graham, 1970). The swine seminal plasma rich in sperm contained higher concentration of Glu than that poor in sperm (Johnson et al., 1972), which suggests a role of spermatozoa in the seminal Glu. However, Glu does not seem to contribute as the energy source for spermatozoa, because supplement of Glu did not significantly affect the oxygen uptake of ram spermatozoa (Setchell et al., 1967). The high concentration of Glu in the caput may, at least in part, be explained as the result of selective resorption of the rete testis fluid (Crabo, 1965). However, the present experiments showed that the concentration of Glu in the caput after ligation of the efferent duct was higher than that in blood plasma and testicular lymph reported by Setchell (1970). Therefore, it is assumed that secretion and metabolism of the epithelial cells also contributed to an amount of Glu in the epididymal fluid from the caput. The high concentration of free amino acids in the caput might be benefical for survival (Mann, 1964) as well as for maturation of the spermatozoon.

After castration, changes in the ratio of Glu to that of Gln in the pressed fluid from the caput epididymis were observed in the present experiments. At the present moment it is not clear whether or not Gln is delivered from epithelial cells and is changed to Glu within the epididymal canal. Metab- olism between Glu and Gln in the organs remains to be clarified.

\section{References}

Back, D. J. (1975). Steroids 25, 413.

Bedford, J. M. and H. I. Calvin (1974). J. Exper. Zool. 187, 181.

Burgos, M. H. and E. S. Tovar (1974). Fertil. \& Steril. 25, 985.

Cooper, T. G. and G. M. H. Waites (1974). J. Endocrinol. 62, 619.

Crabo, B. (1965). Acta Vet. Scand. 6, Suppl. 5, 1.

Danzo, B. J., B. C. Eller and M. C. Orgebin-Crist (1974). Steroids 24, 107.

Dyson, A. L. M. B. and M. C. Orgebin-Crist (1973). Endocrinology. 93, 391.

French, F. S. and E. M. Ritzen (1973). Endocrinology 93, 88.

Ganjam, V. K. and R. P. Amann (1973). Acta Endocrinol. 74, 186.

Hamilton, D. W., Reproductive Biology, Balin, H. and S. Glasser (Ed.) Excerpta Med., Amsterdam, p. 268, 1972.

Hansson, V., O. Djøseland, E. Reusch, A. Attramadal and O. Torgersen (1973a). Steroids 21, 457.

Hansson, V., O. Djøseland, E. Reusch, A. Attramadal and O. Torgersen (1973b). Ibid. 22, 19.

Johnson, L. A., V. G. Pursel, R. J. Gerrits and C. H. Thomas (1972). J. Animal Sci. 34, 430.

Mann, T. The Biochemistry of Semen and of the Male Reproductive Tract, Methuen \& Co., London, p. 162, 1964.

Mushahwar, I. K. and R. E. Koeppe (1973). Biochem. J. 132, 353.

Orgebin-Crist, M. C. (1969). Biol. Reprod. 1, 155.

Orgebin-Crist, M. C. (1973). J. Exper. Zool. 185, 301.

Pace, M. M. and E. F. Graham (1970). Biol. Reprod. 3, 140.

Rajalakshmi, M. and M. R. N. Prasad (1971). J. Reprod. Fertil. 24, 409.

Reid, B. L. and K. W. Cleland (1957). Austral. J. Zool. 5, 223.

Riar, S. S., B. S. Setty and A. B. Kar (1973). Fertil. \& Steril. 24, 355.

Ritzen, E. M., C. Dobbins, D. J. Tindall, F. S. French and S. N. Nayfeh (1973). Steroids 21, 593.

Setchell, B. P., The Testis Vol. 1, Johnson, A. D., W. R. Gomes and N. L. Vandemark (Ed.) Acad. Press, N.Y. \& London, p. 101, 1970.

Setchell, B. P. (1974). J. Reprod. Fertil. 37, 165.

Setchell, B. P., N. T. Hinks, J. K. Voglmayr and T. W. Scott (1967). Biochem. J. 105, 1061.

Sexton, T. J., R. P. Amann and R. J. Flipse (1971). J. Dairy Sci. 54, 412.

Spackman, D. H., W. H. Stein and S. Moore (1958). Analyt. Chem. 30, 1190. 
Stein, W. H. and S. Moore (1954). J. Biol. Chem. Tuck, R. R., B. P. Setchell, G. M. H. Waites and 211, 915.

J. A. Young (1970). Pflügers Arch. 318, 225.

Tindall, D. J., V. Hansson, W. S. McLean, E. M. Weddington, S. C., W. S. McLean, S. N. Nayfeh, Ritzen, S. N. Nayfeh and F. S. French (1975). F. S. French, V. Hansson and E. M. Ritzen (1974). Mol. Cell. Endocrinol. 3, 83. Steroids 24, 123. 